\title{
PROCEEDINGS OF THE FORTY-THIRD ANNUAL MEETING
}

\author{
By Aaron M. Bagg, Secretary
}

The Forty-third Annual Meeting of the Wilson Ornithological Society was held at Purdue University, Lafayette, Indiana, from Thursday, 5 April, to Sunday, 8 April 1962. The meeting was sponsored by the Indiana Audubon Society, the Purdue University Club (Bird Study Section), the Amos W. Butler Audubon Society of Indianapolis, and the South Bend Audubon Society. The Local Committee, under the efficient direction of Dr. R. E. Mumford, Chairman, organized an excellent meeting, which was greatly enjoyed by the 232 registered members and guests who attended.

Four sessions were devoted to papers, and two business meetings were held, in the Purdue Memorial Center. The meeting opened with an informal reception in the Memorial Union on Thursday evening, for which the South Bend Audubon Society and the Amos W. Butler Audubon Society of Indianapolis acted as hosts. Thursday evening was also the occasion for the meeting of the Executive Council, in the Memorial Center. On Friday evening, there was a fascinating colored slide program on the Timber Wolf and Moose populations of Isle Royale National Park. The Annual Dinner was held on Saturday evening in the Memorial Union. The President's Address was presented by Harold F. Mayfield, and was followed by an illustrated program, by Robert A. Mann, on "The Physiography and Natural History of the Indiana Dunes." The Local Committee had decorated the dinner tables attractively, and at each place setting there was a souvenir ash tray shaped in the outline of Indiana and carrying the portrait of a Cardinal.

Early-morning field trips were scheduled for Friday and Saturday. On Sunday, there were field trips to the Willow Slough State Game Preserve, Jasper-Pulaski, and the Greater Prairie Chicken grounds; some of the more interesting species seen included Sandhill Cranes, a few Prairie Chickens, 22 Smith's Longspurs, Yellow Rail, and-as a remarkable bonus - a rare gull which, when subsequently collected, proved to be a Lesser Black-backed Gull.

\section{First Business Session}

President Mayfield called the meeting to order at 9:30 AM, Friday, 6 April. Dr. W. L. Ayres, Dean of the School of Science, Education, and Humanities, Purdue University, welcomed the members and guests of the Wilson Ornithological Society. President Mayfield responded on behalf of the Society.

The Proceedings of the Forty-second Annual Meeting were approved as published in The Wilson Bulletin for September 1961.

\section{Secretary's Report}

The secretary, Aaron M. Bagg, summarized the principal actions taken at the Thursday evening meeting of the Executive Council, as follows:

1. The Council heard further plans for the previously accepted invitation to the Wilson Society to hold its 1963 meeting at Charleston, S.C., during 2-5 May 1963. The sponsoring organizations will be the Charleston Museum, the Charleston Natural History Society, and the Carolina Bird Club.

2. The Council voted to accept the invitation of Western Michigan University, Kalamazoo College, Michigan Audubon Society, the Audubon Society of Kalamazoo, and the Kalamazoo Nature Center, to hold the 1964 meeting of the Wilson Society in Kalamazoo, Michigan, in late April or early May 1964. 
3. The Council voted tentative acceptance of an invitation from the South Dakota Ornithological Society to meet in the Black Hills of South Dakota in June 1965.

4. The Council accepted the report of the Louis Agassiz Fuertes Research Committee and voted an award of $\$ 100$ to Donald S. Heintzelman for his research project.

5. The Council re-elected Dr. H. Lewis Batts, Jr., as Editor of The Wilson Bulletin.

\section{Treasurer's Report}

The treasurer, Merrill Wood, submitted the following report on the finances of the Society:

\section{REPORT OF THE TREASURER FOR 1961}

General Fund

Balance as shown by last report dated 31 December 1960

RECEIPTS

Dues:

Active Memberships

$\$ 4,922.60$

Sustaining Membership

$912.00 \quad \$ 5,834.60$

Subscriptions to The Wilson Bulletin

835.25

Sale of back issues of The Wilson Bulletin

521.85

Interest and dividends on savings and investments $1,139.95$

Transfer from Special Publications Fund (closed)

Gifts

Miscellaneous

Total Receipts

DISBURSEMENTS

The Wilson Bulletin (printing and engraving) $\$ 6,757.37$

The Wilson Bulletin (mailing and maintenance of mailing) 932.40

Secretary's expense

Treasurer's expense (printing, postage, safe deposit box) 276.62

Back issue expense (postage and purchases)

International Council for Bird Preservation (1961 dues)

Annual Meeting expense 236.88

Transfer to Fuertes' Research Fund

Miscellaneous

\section{Total Disbursements}

Balance on hand in First National Bank, State College, Pennsylvania,

31 December 1961

Josselyn Van Tyne Memorial Library Book Fund

Balance as shown by last report dated 31 December 1960 RECEIPTS

Sale of duplicates and gifts $\$ 342.05$

Total Receipts

DISBURSEMENTS

Purchase of books

Balance on hand in First National Bank, State College, Pennsylvania, 


\section{Louis Agassiz Fuertes Research Fund}

Balance as shown by last report dated 31 December 1960

$\$ 127.00$ RECEIPTS

Contributions

Transfer from General Fund (Council action)

$\$ \quad 17.00$

Total Receipts

\section{DISBURSEMENTS}

Award to Frances (Mrs. Douglas A.) James

$\$ \quad 100.00$

Balance on hand in First National Bank, State College, Pennsylvania,

31 December 1961

$\$ 100.00$

\section{ENDOWMENT Fund}

Balance in Savings Account as shown by last report dated 31

December 1960

RECEIPTS

Life Membership payments

$\$ 1,232.00 \quad \$ 1,232.00$

Stock dividends received (included below)

5 shares of Massachusetts Investors Trust

Total Receipts

DISBURSEMENTS

Purchase of 70 shares of M. A. Hanna Co.

$\$ 2,380.00 \quad \$ 2,380.00$

Balance in Savings Account, First National Bank, State College,

Pennsylvania, 31 December 1961

Total

SECURITIES OWNED

$\$ 5,000$ U.S. Treas. $4 \%$ Notes due 15 May 1963 at 10028/32

$\$ 5,043.75$

$\$ 5,000$ U.S. Treas. $4 \%$ Bonds due 1 October 1969 at $10022 / 32$

$5,034.40$

$\$ 3,000$ Phillips Petroleum 41丷2\% Bonds due 15 February

1987 at 123

70 shares M. A. Hanna Co. at $33^{1 / 8}$

15 shares Kaiser Aluminum \& Chemical Co. 43\%4\% cum. cvt. pft.

(1957 series) at $106 \%$

401 shares Massachusetts Investors Trust at 15.55

100 shares Fireman's Fund Insurance at $63 \frac{1}{2}$

25 shares Owens-Illinois Glass Co. $4 \%$ com. pfd. at 114

(Securities listed at closing prices 29 December 1961)

Total Securities Owned

Total in Endowment Fund, 31 December 1961

Respectfully submitted, /s/ Merrill Wood Treasurer

The Society voted to accept the Treasurer's Report.

\section{Research Grant Committee}

Pershing B. Hofslund spoke briefly on the work of the committee, of which Harvey I. Fisher is Chairman. 


\section{Membership Committee}

Hazel Bradley Lory, Chairman, reported as follows:

The Membership Committee this year has consisted of 18 members, well distributed over the United States, and one in Canada.

For my part, I have endeavored to keep my assistants supplied with the necessary leaflets, application-for-membership cards and past numbers of the Bulletin, wherever usable. $\mathrm{I}$ have also taken care of individual requests for information about membership that have been sent to me.

Before last year's annual meeting I requested that a list of all people attending, with their addresses, be supplied to me following the meeting. This was sent to me very promptly and I used it for listing prospective members. It was checked against our latest membership list and I found 76 non-members had attended. Their names, in groups of 8 to 12 , were sent to members of our committee, who then wrote to these people inviting them to join W.O.S. Twelve members were secured in this way.

According to a report from the Treasurer on the number of new members obtained through sponsorship of W.O.S. members, ten members of our committee secured 31 new members. Twenty joined without sponsorship and the rest were sponsored by other members not on our committee.

For the 1962 meeting I have brought a supply of application cards, leaflets and Bulletins to be given out to anyone interested in joining. Also, at the suggestion of our President, I have prepared packets of Bulletins to be given as "bonuses" to those who join the Society during this meeting.

\section{Library Committee}

William A. Lunk, Chairman, reported by letter as follows:

During the past year the business of the Library Committee has been largely of a routine nature - no formal meetings have been called.

In line with the continuing policy of reducing the supply of back issues, certain contributions of Wilson Bulletins have been made to particularly worthy institutions or organizations, particularly overseas, where it has appeared that the journal would receive wide use and that it would be otherwise unavailable.

Sale of duplicates from the Josselyn Van Tyne Memorial Library, with proceeds to go into the New Book Fund, is continuing, and being increasingly emphasized. Donors should understand that salable duplicates can ultimately be of just as much value to the organization as entirely new items. As the New Book Fund has grown, increased use is being made of it to purchase needed publications. Those requested, which we cannot furnish, will be considered for purchase. It is also contemplated that certain valuable works could, by binding, be made far more durable and usable through judicious use of this fund. Up-to-date figures on the present standing of the fund and on our income and disbursements are not immediately available, but should appear in the Treasurer's report.

Through a new plan tentatively being put into effect at the present meeting, newly acquired books are to be exhibited at the annual meeting. Arrangements with one publisher, and perhaps later with others, provide for a contribution of current books to the library, in exchange for the publicity afforded by their display to our membership in this manner.

The formal incorporation of the library of the late Josselyn Van Tyne continues, this year with Mrs. Van Tyne's gift of 85 books and the equivalent of 20 volumes of separates.

Total acquisitions, from 70 gifts by 63 donors were: 162 books, 251 journals, 6 pam- 
phlets, 14 translations, and 625 reprints. The 107 journals regularly received, 82 by exchange and 25 as gifts, remain as last year.

During the year, 35 out-of-town loans were made to 30 individuals. By far the greatest use is still made of the library by those who come in person.

It is hoped that increased publicity may lead to far greater use, by the members, of our rapidly growing library resources - and in turn to even better support of our endeavors. The thanks of the Committee are extended to all those who have contributed.

\section{Temporary Committees}

The President appointed the following temporary committees:

\section{Auditing Committee}

David E. Davis, Chairman

George Grube

Carl W. Helms

\section{Nominating Committee}

Burt L. Monroe, Sr., Chairman

Maurice G. Brooks

John T. Emlen, Jr.

\section{Resolutions Committee}

Haven H. Spencer, Chairman

Leonard Brecher

Ralph Dexter

\section{Second Business Session}

The final business session was called to order at 3:00 PM, Saturday, 7 April.

On motion duly made and seconded, the report of the Membership Committee was accepted, and the candidates (as posted) were elected to membership in the Society.

\section{Report of the Auditing Committee}

The committee reported by letter that they had examined the books of the Wilson Ornithological Society at State College, Pennsylvania, on 2 April 1962, and found them in good order. The report added: "Dr. Wood should be commended for the excellent condition, neat and prompt entries" in the books.

On motion duly made and seconded, the report of the Auditing Committee was accepted.

\section{Report of the Resolutions Committee}

Haven H. Spencer, Chairman, read the following report:

WHEREAS the Wilson Ornithological Society is in session at its Forty-third Annual Meeting at Purdue University, Lafayette, Indiana,

BE IT RESOLVED that the Society express its appreciation to the Local Committee under the leadership of Dr. Russell E. Mumford, chairman, and Mrs. William L. Ayres, Mrs. Arthur M. Brunson, Dr. and Mrs. Irving W. Burr, Mrs. Donald T. Canfield, Prof. and Mrs. Karleton W. Crain, Mrs. Samuel S. Cromer, Mrs. Marvin W. DeJonge, Dr. and Mrs. H. D. Jackson, Dr. and Mrs. Charles M. Kirkpatrick, Mrs. Warren M. McVey, Dr. and Mrs. George P. Salen, Dr. and Mrs. Aubrey H. Smith, Dr. J. Dan Webster, and Dr. and Mrs. Merritt S. Webster, for the careful planning and organization which has made 
this meeting so enjoyable and interesting to the Wilson Ornithological Society's members and friends,

AND BE IT FURTHER RESOLVED that the Society express its thanks to the Indiana Audubon Society, to the Purdue University Club (Bird Study Section), to the Amos W. Butler Audubon Society of Indianapolis, and to the South Bend Audubon Society, for their hospitality in providing refreshments, transportation, and leadership for field trips,

AND BE IT FURTHER RESOLVED that the Society express its appreciation to the Administration and Faculty of Purdue University for their cooperation in the use of their excellent facilities,

AND BE IT FURTHER RESOLVED that the Society express its appreciation to Mr. Harold F. Mayfield for his devoted service and leadership in his two years as president of the Wilson Ornithological Society, and to Mr. Aaron Bagg for his years of devoted service to the Society,

AND BE IT FURTHER RESOLVED that the Society urge its members, as individuals, to participate more actively in correspondence with their governmental representatives concerning conservation issues, the need for wilderness areas, and better-administrated predator, pesticide, and vegetative controls in the management of our wildlife,

AND BE IT FURTHER RESOLVED that the Society express its support of Senate Bill S-1797 that proposes to create an Indiana Dunes National Park, as a unique biological preserve.

On motion duly made and seconded, the report of the Resolutions Committee was accepted.

\section{Election of Officers}

The Nominating Committee proposed the following officers for the coming year: President, Phillips B. Street; First Vice-President, Roger Tory Peterson; Second VicePresident, Aaron M. Bagg; Secretary, Pershing B. Hofslund; Treasurer, Merrill Wood; Elective Member of the Executive Council, Kenneth C. Parkes (term expiring 1965).

The report of the committee being accepted, and there being no nominations from the floor, the Secretary was instructed to cast a unanimous ballot for these nominees.

$$
\begin{aligned}
& \text { Papers Sessions } \\
& \text { Friday, } 6 \text { April }
\end{aligned}
$$

1. Robert W. Storer, Museum of Zoology, University of Michigan. Observations on the Great Grebe.

2. Lawrence H. Walkinshaw, Battle Creek, Michigan. Observations on Three of Africa's Crowned Cranes.

3. R. M. Evans, University of Wisconsin. Measurement of Dancing Ground Territories in Sharp-tailed Grouse (Pedioecetes phasianellus).

4. Elden W. Martin, University of Illinois. Body Weight, and Molt Effects in House Sparrows (Passer domesticus domesticus) Fed Diets of Different Protein Levels.

5. S. Charles Kendeigh, University of Illinois. Regulation of Nesting Time in the House Wren.

6. Ralph W. Dexter, Kent State University, Kent, Ohio. Orientation of the Common Nighthawk to Direction of Sunlight on the Nesting Grounds.

7. Richard Brewer, Western Michigan University. Parental Care in the Great Crested Flycatcher and Eastern Kingbird. 
8. John A. Wiens, University of Wisconsin. Aspects of Cowbird Parasitism in Southern Oklahoma.

\author{
Saturday, 7 April
}

9. John L. Zimmerman, University of Illinois. The Vernal Migration of the Dickcissel, a Winter Resident in the Tropics.

10. James E. Landing, Michigan City, Indiana. Geographic Field Work in the Study of Avian Migration.

11. Pershing B. Hofslund, University of Minnesota, Duluth. The Duluth Hawk Flyway: 1951-1961.

12. Francois Vuilleumier, Schweizerische Vogelwarte, and University of Illinois. Fall Migration of Birds over the Swiss Alps.

13. William L. Thompson and Ellen L. Coutlee, Wayne State University, Detroit. Biology and Population Structure of Starlings at an Urban Roost.

14. Irving W. Burr, Purdue University. Statistical Methods Useful to Ornithologists.

15. J. Hill Hamon, Indiana State College. The Avifauna of the Reddick, Florida, Pleistocene.

16. Harold F. Mayfield, Waterville, Ohio. Changes in the Bird Life of the Toledo Region Since the Coming of the White Man.

17. Leon Kelso, Washington, D.C., and Margaret M. Nice, Chicago, Illinois. A Russian Contribution to Anting and Feather Mites.

18. Hugh C. Land, Concord College, Athens, West Virginia. A Tropical "Feeding Tree."

Attendance

Members and guests who registered totaled 232 persons. Fifteen states, plus the District of Columbia, were represented.

From Connecticut: 1-New Haven, Mary Heimerdinger.

From Illinois: 26-Champaign, S. Charles Kendeigh, Francois Vuilleumier, John E. Williams, John L. Zimmerman; Chicago, Albert Gilbert, Mr. and Mrs. L. B. Nice, Dr. and Mrs. A. L. Rand; Danforth, Herman Smith; Decatur, Mr. and Mrs. C. Turner Nearing; Dekalb, Fred Moyer, William E. Southern, James Tate, Jr., Jerold Zar; East Moline, Mr. and Mrs. Elton Fawks; Momence, Mr. and Mrs. William T. Lory, Mrs. R. J. Sprinkle; Peoria, Ferd Luthy; Quincy, T. E. Musselman; Urbana, T. C. Jegla, Elden Martin, R. E. Yeatter.

From Indiana: 101-Bloomington, Robert A. Johnston; Connersville, Edna Banta; Culver, Mr. and Mrs. Robert McIlwain; Fort Wayne, Marie Miller, Edith Paul, Iva Spangler, Mabel Thorne; Gary, Raymond Grow; Hamlet, Mr. and Mrs. J. P. Buck; Hanover, J. Dan Webster; Huntington, Mayretha Plasterer; Indianapolis, Mrs. Ferd Barnickle, Charles S. Berriman III, Robert Buskirk, William Buskirk, Mrs. S. G. Campbell, Mildred Campbell, Paul K. Cullen, Peter D. Cullen, Charles E. Keller, Mrs. Dorothy Luther, Betty Jean Moore, Clara Alma Moore, John Satter, Mrs. Dollie Stuck, Henry C. West, Dorothy White; Lafayette, Mr. and Mrs. W. L. Ayres, Henrietta Ball, Mr. and Mrs. John H. Miller, Dr. and Mrs. Russell Mumford, Mary Frances Seever; LaGrange, Mrs. Bertha Thompson; La Porte, Mr. and Mrs. W. W. Nicholson; Marion, Mrs. Ella Hart; Michigan City, James Landing, Mr. and Mrs. Robert A. Mann; Muncie, Mrs. Robert H. Allen, Thomas G. Overmire, Mr. and Mrs. Harold Zimmerman; New Castle, Mr. and Mrs. C. L. Gough; Pendleton, Mr. and Mrs. Joseph Brinduse, Ruth Dickenson, Robert Martin, Mr. and Mrs. Fred 
Miller, David Smith, Steven Smith, David Walker; Richmond, Wilson Baker, James Cope, James Gesseman, Cameron Gifford, Mrs. C. S. Snow, Gertrude Ward; South Bend, Mr. and Mrs. John Groet, Mr. and Mrs. R. V. Rea, Mr. and Mrs. G. W. Vesey; Terre Haute, Mrs. Edward Erickson, J. Hill Hamon, Mrs. Edward Malooley, Mrs. James H. Mason; West Lafayette, Mr. and Mrs. A. M. Brunson, Mr. and Mrs. Irving Burr, Peter Burr, Mr. and Mrs. D. T. Canfield, Mrs. S. S. Cromer, Mr. and Mrs. Harold Dick, Mr. and Mrs. Clarence Goodnight, Mr. and Mrs. H. D. Jackson, Karl Jackson, Mr. and Mrs. Charles Kirkpatrick, Mrs. C. Mahan, Mr. and Mrs. Stuart McLain, Mrs. Beatrice Meehan, Mr. and Mrs. Howard Michaud, Mrs. A. H. Smith, Mr. and Mrs. Merritt S. Webster.

From Iowa: 2-Davenport, Mary Lou Petersen, Pete Petersen, Jr.

From Kentucky: 11-Anchorage, Mr. and Mrs. Burt L. Monroe, Sr.; Louisville, Mr. and Mrs. Leonard Brecher, Evelyn J. Schneider, Mabel Slack, Mr. and Mrs. Frederick Stamm, Audrey A. Wright; Richmond, Tom Hutto, Dan Schreiber.

From Massachusetts: 2-Dover, Mr. and Mrs. Aaron M. Bagg.

From Michigan: 35-Ann Arbor, Paul R. Barker, A. J. Berger, Jean Cohn, Norman L. Ford, John Hubbard, Bertram Murray, Jr., Haven Spencer, Robert W. Storer, H. B. Tordoff; Battle Creek, Dr. and Mrs. Lawrence H. Walkinshaw; Detroit, William Thompson, Elsie Townsend; East Lansing, Robert Fleming, R. M. Naik, George J. Wallace; Grand Haven, Jack Kammeraad; Kalamazoo, Lewis Batts, Richard Brewer, Helen E. Burrell, Charlotte Calhoun, Monica Evans, Anne V. Fuller, Richard Koerker, Thane Robinson, James Spaulding, Marie E. Thompson; Leonard, Mrs. Alice D. Miller; Marquette, Mary Ross; Mount Pleasant, Larry D. Caldwell, N. L. Cuthbert, Harold D. Mahan; Union City, Mr. and Mrs. W. A. Dyer; W arren, Sergej Postupalsky.

From Minnesota: 2-Duluth, P. B. Hofslund; Minneapolis, Walter J. Breckenridge.

From Nebraska: 2-Wisner, Mr. and Mrs. John Lueshen.

From New York: 5-Buffalo, Mrs. Kathleen Allen, Richard C. Rosche; Hamburg, Kenneth Able; Ithaca, Dr. and Mrs. O. S. Pettingill, Jr.

From Ohio: 24-Ashtabula, Howard E. Blakeslee; Chardon, Marjorie Ramisch; Cincinnati, E. Kemsies; Cleveland, Adela Gaede, Mildred Stewart; Columbus, W. T. Furniss, Charles B. Wheeler; Dayton, Mr. and Mrs. Kenneth L. Meyers; East Cleveland, Vera Carrothers; Kent, Ralph Dexter; Lakewood, Mr. and Mrs. William A. Klamm; Momence, Mrs. Lessly Fieleke; Steubenville, Earl Farmer; Toledo, John M. McCormick, Lois McCormick; Utica, Mr. and Mrs. C. R. Wagner; Waterville, Charles Mayfield, Mr. and Mrs. Harold Mayfield, John Mayfield, Melinda Mayfield.

From Pennsylvania: 5-Chester Springs, Phillips B. Street; Philadelphia, C. Chandler Ross; Pittsburgh, Kenneth Parkes; State College, Dr. and Mrs. Merrill Wood.

From Tennessee: 2-Nashville, Albert J. Ganier, John Ogden.

From West Virginia: 4 -Athens, Mr. and Mrs. Hugh Land; Ona, Mrs. Ben W. Kiff, Lloyd Kiff.

From Wisconsin: 9-Madison, Earl Bishop, Dr. and Mrs. John T. Emlen, Roger Evans, Don E. Miller, Helmut Mueller, Victor Rabinowitch, Emil K. Urban, John A. Wiens. From the District of Columbia: 1-Orville W. Crowder. 


\section{$2 \mathrm{BHL}$ Biodiversity Heritage Library}

Bagg, Aaron M. 1962. "Proceedings of the Forty-Third Annual Meeting." The Wilson bulletin 74(3), 305-312.

View This Item Online: https://www.biodiversitylibrary.org/item/216031

Permalink: https://www.biodiversitylibrary.org/partpdf/214417

\section{Holding Institution}

Harvard University, Museum of Comparative Zoology, Ernst Mayr Library

\section{Sponsored by}

IMLS LG-70-15-0138-15

\section{Copyright \& Reuse}

Copyright Status: In copyright. Digitized with the permission of the rights holder.

Rights Holder: Wilson Ornithological Society

License: http://creativecommons.org/licenses/by-nc-sa/4.0/

Rights: https://biodiversitylibrary.org/permissions

This document was created from content at the Biodiversity Heritage Library, the world's largest open access digital library for biodiversity literature and archives. Visit BHL at https://www.biodiversitylibrary.org. 